\title{
Effects of the Method of Conservation of Timothy on Nitrogen Metabolism in Lactating Dairy Cows
}

\author{
R. Martineau, ${ }^{*}$ H. Lapierre, $\nmid$ D. R. Ouellet, $\dagger$ D. Pellerin, ${ }^{*}$ and R. Berthiaume ${ }^{1}$ \\ *Département des Sciences Animales, Université Laval, Québec, Québec, Canada G1K 7P4 \\ †Dairy and Swine Research and Development Centre, Agriculture and Agri-Food Canada, Sherbrooke, Québec, Canada J1M 1 Z3
}

\begin{abstract}
Six ruminally and duodenally cannulated lactating primiparous Holstein cows were used to study the effects of different methods of conservation of timothy on $\mathrm{N}$ metabolism. Cows were assigned randomly to 2 replicated $3 \times 3$ Latin squares ( 35 -d periods). Because of missing data from 2 cows, data were analyzed as a $3 \times 4$ Youden square. Diets contained a similar concentrate ( $44 \%$ of total ration on a dry matter basis) plus first-cut timothy conserved as hay, or as restrictively (formic) or extensively fermented silage (inoc). Crude protein contents were $10.4,13.6$, and $14.8 \%$ for hay, formic, and inoc, respectively. Hay and formic had a high soluble carbohydrate content $(\geq 8.0 \%$ of dry matter) and formic and inoc had a high soluble protein content ( $\geq 8.0 \%$ of dry matter). Haying and restricting fermentation resulted in increased efficiency of partition to milk $\mathrm{N}$ (30.9, 28.2, 24.7\% of $\mathrm{N}$ intake for hay, formic, and inoc, respectively). Despite a $14 \%$ lower $\mathrm{N}$ intake with hay, no effects of treatments were detected on microbial protein synthesis and apparent intestinal digestion of essential AA. Haying reduced feed protein degradation in the rumen, whereas this effect was not observed when restricting fermentation in the silage. Haying and restricting fermentation induced a lipogenic fermentation pattern in the rumen $(4.55,4.23$, and 3.78 ratio of acetate to propionate for hay, formic, and inoc), but no effects on milk fat yield and plasma glucose were observed. Whole-body protein metabolism was unaffected by treatments.
\end{abstract}

Key words: dairy cow, metabolism, timothy, nitrogen

\section{INTRODUCTION}

Prior to harvest, more than $75 \%$ of the total $\mathrm{N}$ in plants is true protein, whereas the remainder is NPN. The proportion of NPN may increase to $40 \%$ when

Received November 16, 2006.

Accepted February 14, 2007.

${ }^{1}$ Corresponding author: berthiaumer@agr.gc.ca the plant is ready to be baled or chopped for silage, depending on the ambient temperature and drying rate. There are generally very small further increases in NPN during storage with hay; however, more proteolysis occurs during ensiling, which may in turn increase NPN up to 60 to $70 \%$ of total N when silage is fed to the animals (Kung and Muck, 2006).

Proteolysis in silage can be reduced by using additives such as formic acid, which artificially acidifies the forage mass, or products that enhance the production of lactic acid (e.g., inoculants, enzymes). Upon application, formic acid induces a rapid drop in $\mathrm{pH}$, whereas silage inoculants bring about a more variable rate of acidification. Their ability to reduce proteolysis therefore differs. Another advantage of silage additives is the decreased catabolism of water-soluble carbohydrates (WSC), which are degraded to support acid synthesis by bacteria (McDonald et al., 1991). Hence, this effect is not as good with silage inoculants because WSC are the main substrate for lactic acid bacteria.

Efficiency of microbial protein synthesis was improved by restricting fermentation during ensiling (Jaakkola et al., 1993; Huhtanen et al., 1997; Verbič et al., 1999). By reducing NPN or increasing capture of $\mathrm{N}$ in the rumen, the use of additives can decrease ammonia absorption with subsequent hepatic urea production and reduce $\mathrm{N}$ losses to the environment. The metabolic fate of body $\mathrm{N}$ is generally studied using $\mathrm{N}$ balance. However, $\mathrm{N}$ balance gives only the net result of much larger opposite dynamic flows, namely, whole-body (WB) protein synthesis and protein breakdown. Those flows are controlled by endocrine, physiological, and nutritional factors such as protein (Lapierre et al., 2002; Raggio et al., 2006) and energy (Raggio et al., 2006) supplies, which can both be affected by the method of conservation of the forage.

We hypothesized that increasing the WSC content and decreasing $\mathrm{N}$ solubility of the forage would improve microbial capture of $\mathrm{N}$ in the rumen, increase milk protein secretion, and decrease urinary $\mathrm{N}$ losses by increasing WB protein synthesis. Therefore, the objective of this experiment was to compare the effects of feeding timothy conserved either as hay or as re- 
strictively or extensively fermented silage on ruminal metabolism, microbial protein synthesis, intestinal flow of nutrients, $\mathrm{N}$ utilization, Leu kinetics, and milk production in lactating dairy cows.

\section{MATERIALS AND METHODS}

Animals were cared for according to the guidelines of the Canadian Council on Animal Care (CCAC, 1993), and all procedures involving animals were previously approved by the Institutional Animal Care Committee of the Dairy and Swine Research and Development Centre.

\section{Forage Production}

Three forages ( 2 silages and 1 hay) were prepared from the same first-cut timothy (Phleum pratense L. cv. Champ) sward mowed on June 18, 2001, from 0900 to $1430 \mathrm{~h}$. The first forage (inoc) was harvested after $20 \mathrm{~h}$ of wilting (1 tedding) and ensiled with an inoculant containing Lactobacillus plantarum LPH-1 and Pediococcus cerevisiae PCH-3 (final application rate of $1.25 \times 10^{5} \mathrm{cfu} / \mathrm{g}$ of fresh forage). The second forage (formic) was harvested after $24 \mathrm{~h}$ of wilting (no tedding) and ensiled with the application of $85 \%$ formic acid at a rate of $6 \mathrm{~L} / \mathrm{t}$ of fresh forage. Both silages were conserved in plastic-tube silos. The third forage (hay) was harvested as small-bale hay. It was tedded 24 and $48 \mathrm{~h}$ after the cut and was raked and baled on June 20,2001 . The drying process was completed in the barn with a hay dryer during $10 \mathrm{~d}$. Weather conditions were good during forage harvesting. Silos were opened after $214 \mathrm{~d}$.

\section{Cows and Diets}

Six primiparous Holstein cows cannulated in the rumen (10 cm; Bar Diamond Inc., Parma, ID) and duodenum (closed T-shaped cannula made of Tefloncoated stainless steel) were used in 2 replicated $3 \times 3$ Latin squares with 35 -d periods. Cows averaged 576 $\pm 77 \mathrm{~kg}$ of BW and $112 \pm 23 \mathrm{DIM}$ at the start of the experiment. Treatments were hay, inoc, or formic supplemented with a concentrate pelleted in a single batch at a local feed mill. The forage was offered at approximately $56 \%$ of the ration DM. Table 1 shows the ingredients and chemical composition of the diets used in the experiment. During the experiment, the ration was restricted at $95 \%$ of ad libitum DMI, as determined during the first week of period 1, to maintain steady-state conditions and minimize variation in DMI within and between experimental periods. Table 2 summarizes the chemical composition of dietary
Table 1. Ingredients and chemical composition of the diets

\begin{tabular}{lrrr}
\hline & \multicolumn{3}{c}{ Diet } \\
\cline { 2 - 4 } Composition & Hay & Formic & Inoc \\
\hline Ingredient, \% of DM & & & \\
Hay (unchopped) & & & \\
Hay (chopped) & 56.2 & - & 5.3 \\
Restrictively fermented silage & - & 51.8 & - \\
Extensively fermented silage & - & - & 48.9 \\
Concentrate & 43.8 & 43.1 & 45.8 \\
Chemical & & & \\
DM, \% & 91.4 & 54.5 & 55.8 \\
OM, \% of DM & 94.2 & 93.3 & 93.0 \\
CP, \% of DM & 12.5 & 14.6 & 15.2 \\
NPN, \% soluble N & 83.4 & 85.7 & 86.1 \\
Soluble protein, \% of DM & 3.7 & 5.5 & 5.9 \\
Neutral detergent insoluble CP, \% of DM & 2.1 & 2.2 & 2.1 \\
Acid detergent insoluble CP, \% of DM & 0.7 & 1.0 & 1.1 \\
NDF, \% of DM & 41.6 & 38.9 & 35.4 \\
ADF, \% of DM & 25.6 & 24.4 & 22.7 \\
\hline
\end{tabular}

${ }^{1}$ Chemical composition: $91.4 \% \mathrm{DM}$, and (\% of DM) $90.5 \% \mathrm{OM} ; 16.1 \%$ $\mathrm{CP} ; 57.6 \% \mathrm{NDF} ; 35.7 \%$ ADF.

${ }^{2}$ Ingredients in the concentrate $(\% \mathrm{DM}$ basis $)=76.1 \%$ ground shelled corn; $13.2 \%$ soybean meal; $4.72 \%$ Megalac; $2.23 \%$ mineral and vitamin premix; $1.52 \%$ dicalcium phosphate; $1.31 \%$ molasses; $0.51 \%$ Lignosol; $0.22 \% \mathrm{MgO} ; 0.20 \% \mathrm{Cr}_{2} \mathrm{O}_{3}$. The mineral and vitamin premix contained (DM basis) $20.2 \% \mathrm{Na} ; 7.8 \% \mathrm{Cl} ; 6.0 \% \mathrm{Ca} ; 0.3 \% \mathrm{P}$; $4.6 \% \mathrm{Mg} ; 0.24 \% \mathrm{~K} ; 1.6 \% \mathrm{~S} ; 58.4 \mathrm{mg} / \mathrm{kg}$ of Co; $5,192 \mathrm{mg} / \mathrm{kg}$ of Mn; $7,788 \mathrm{mg} / \mathrm{kg}$ of Zn; $31.2 \mathrm{mg} / \mathrm{kg}$ of Se; $280 \mathrm{mg} / \mathrm{kg}$ of Fe; 700,940 IU of vitamin A/kg; 155,760 IU of vitamin D/kg; 2,336 IU of vitamin $\mathrm{E} / \mathrm{kg}$.

ingredients offered during the experiment. Animals were housed in individual tie stalls equipped with rubber mats and had free access to water throughout the trial. Adaptation to experimental treatments was from d 1 to 16 , milk yield and sampling and total collection of feces and urine were from d 17 to 21, Leu kinetics were on d 26 and 27, and rumen and blood sampling were on $\mathrm{d} 34$ and 35 .

\section{Feed Intake}

All diets were fed as TMR and distributed every other hour in 12 equal meals per day with automated feeders (Ankom Technology, Fairport, NY). The hay was coarsely chopped [2 to 3 in. long 5 to $8 \mathrm{~cm}$ )] to facilitate delivery through the automated feeders. In both the formic and inoc diets, $1 \mathrm{~kg}$ (as-is basis) of unchopped hay was fed to prevent ruminal disturbances. Feed consumption was recorded daily by weighing feeds offered to and refused by the cows. Samples of TMR, feed ingredients, and orts were collected daily and kept frozen. Samples were composited by period, freeze-dried, ground through a 1-mm screen Wiley mill (standard model 4; Arthur H. Thomas, Philadelphia, PA), and analyzed for DM, OM, total N, NPN, soluble protein, CP insoluble in neutral or acid detergent, NDF, ADF, and AA concentrations. Fresh silage extracts were analyzed for $\mathrm{pH}$ with an Accumet 
Table 2. Chemical composition and fermentation characteristics of dietary ingredients

\begin{tabular}{|c|c|c|c|c|}
\hline Item & Hay & $\begin{array}{l}\text { Restrictively } \\
\text { fermented } \\
\text { silage }\end{array}$ & $\begin{array}{l}\text { Extensively } \\
\text { fermented } \\
\text { silage }\end{array}$ & Concentrate \\
\hline \multicolumn{5}{|l|}{ Chemical composition } \\
\hline $\mathrm{DM}, \%$ & 91.9 & 39.9 & 39.6 & 90.7 \\
\hline $\mathrm{OM}, \%$ of $\mathrm{DM}$ & 95.3 & 94.3 & 93.5 & 92.7 \\
\hline $\mathrm{CP}, \%$ of $\mathrm{DM}$ & 10.4 & 13.6 & 14.8 & 15.0 \\
\hline NPN, \% soluble $\mathrm{N}$ & 88.4 & 89.2 & 92.4 & 74.3 \\
\hline Soluble protein, \% of DM & 4.6 & 8.0 & 8.2 & 2.0 \\
\hline Neutral detergent insoluble CP, \% of DM & 3.4 & 3.4 & 3.3 & 0.5 \\
\hline Acid detergent insoluble $\mathrm{CP}, \%$ of $\mathrm{DM}$ & 0.8 & 1.5 & 1.5 & 0.5 \\
\hline $\mathrm{NDF}, \%$ of DM & 68.2 & 63.7 & 59.2 & 7.8 \\
\hline $\mathrm{ADF}, \%$ of $\mathrm{DM}$ & 43.5 & 41.7 & 39.0 & 2.9 \\
\hline WSC, $1 \%$ of DM & 8.0 & 9.3 & 4.3 & - \\
\hline \multicolumn{5}{|l|}{$\mathrm{AA}, \%$ of $\mathrm{CP}$} \\
\hline Arg & 4.2 & 3.7 & 2.7 & 5.7 \\
\hline His & 1.7 & 1.8 & 1.6 & 2.5 \\
\hline Ile & 3.8 & 4.2 & 4.1 & 3.9 \\
\hline Leu & 6.5 & 7.0 & 6.9 & 9.1 \\
\hline Lys & 4.1 & 4.7 & 4.5 & 4.3 \\
\hline Met & 1.6 & 1.6 & 1.5 & 1.9 \\
\hline Phe & 4.3 & 4.6 & 4.3 & 4.6 \\
\hline Thr & 4.1 & 4.3 & 4.1 & 3.8 \\
\hline Trp & 2.0 & 1.6 & 1.3 & 1.5 \\
\hline Val & 5.1 & 5.5 & 5.6 & 4.9 \\
\hline Ala & 5.7 & 6.4 & 6.3 & 5.7 \\
\hline Asx & 9.3 & 9.5 & 8.8 & 9.2 \\
\hline Cys & 1.1 & 0.7 & 0.6 & 1.9 \\
\hline Glx & 9.1 & 9.0 & 7.4 & 17.9 \\
\hline Gly & 4.6 & 4.7 & 4.4 & 4.1 \\
\hline Pro & 6.4 & 5.2 & 4.7 & 7.0 \\
\hline Ser & 4.0 & 4.0 & 3.1 & 4.9 \\
\hline Essential AA & 37.3 & 38.8 & 36.8 & 42.0 \\
\hline Nonessential AA & 40.1 & 39.4 & 35.4 & 50.6 \\
\hline Branched-chain AA & 15.3 & 16.7 & 16.7 & 17.8 \\
\hline Total AA & 77.4 & 78.2 & 72.2 & 92.6 \\
\hline \multicolumn{5}{|l|}{ Fermentation characteristics } \\
\hline $\mathrm{pH}$ & - & 4.2 & 4.4 & - \\
\hline $\mathrm{NH}_{3}-\mathrm{N}, \%$ of total $\mathrm{N}$ & - & 4.5 & 6.7 & - \\
\hline Lactic acid, $\%$ of DM & - & 3.8 & 9.0 & - \\
\hline Acetic acid, \% of DM & - & 0.7 & 1.5 & - \\
\hline Propionic acid, \% of DM & - & 0.02 & $<0.01$ & - \\
\hline Butyric acid, \% of DM & - & 0.03 & $<0.01$ & - \\
\hline
\end{tabular}

${ }^{1} \mathrm{WSC}=$ water-soluble carbohydrates (Dubois et al., 1956).

pH meter (model 815 MP; Fisher Scientific, Fairlawn, $\mathrm{NJ}$ ), and frozen at $-20^{\circ} \mathrm{C}$ for later determination of WSC, $\mathrm{NH}_{3}-\mathrm{N}$, lactic acid, and VFA concentrations.

\section{Ruminal Fermentation Characteristics and Duodenal Sampling}

Ruminal digesta was sampled at 0900, 1100, 1300, and $1500 \mathrm{~h}$ on $\mathrm{d} 34$ and at $0800,1000,1200$, and 1400 $\mathrm{h}$ on $\mathrm{d} 35$. Ruminal samples were strained through 2 layers of cheesecloth. Ruminal $\mathrm{pH}$ was measured immediately after sampling (Piccolo pH meter; Hanna Instruments, Woonsocket, RI), and subsamples were acidified to $\mathrm{pH} 2$ with sulfuric acid (50\% vol/vol; $1: 17$ $\mathrm{wt} / \mathrm{wt}$ acid:rumen fluid) and frozen at $-20^{\circ} \mathrm{C}$ for later determination of VFA, lactic acid, and $\mathrm{NH}_{3}-\mathrm{N}$ concentrations. The same collection schedule was used for duodenal samples. Ruminal and duodenal subsamples were formolized $(75 \mathrm{~mL}$ of formol saline added to 300 $\mathrm{mL}$ of digesta) and stored at $-20^{\circ} \mathrm{C}$ until analyses. Chromium sesquioxide $\left(\mathrm{Cr}_{2} \mathrm{O}_{3}\right)$ was used as an indigestible marker. It was mixed with ground shelled corn (7.5/80.0, wt/wt as-is basis) and $21.5 \mathrm{~kg}$ of this premix was included with the other ingredients of the concentrate before pelleting. Calculations of flows through the duodenum were based on the amounts of $\mathrm{Cr}$ excreted during the total collection of feces.

\section{Milk Production and Milk Composition}

Cows were milked twice daily in their stalls at approximately 0800 and $1600 \mathrm{~h}$, and milk yield was recorded at each milking. Milk samples were collected from each cow at each milking from d 17 (p.m.) to 
d 22 (a.m.). Milk subsamples were kept frozen until analyzed for fat, protein, and lactose content. Milk subsamples were pooled on a yield basis and kept frozen until analyzed for urea $\mathrm{N}$ and noncasein $\mathrm{N}$ content. Averages were then calculated for each cow at each period.

\section{Apparent Total Tract Digestibility and $\mathbf{N}$ balance}

Urine was collected in stainless-steel containers via a Gooch tube (BF Goodrich Co., Kitchener, ON, Canada) and acidified with sulfuric acid (50\% vol/vol; 125 $\mathrm{mL}$ at 0800,1400 , and $2000 \mathrm{~h}$ ) to maintain $\mathrm{pH}<3.0$. A representative sample (2\%) was taken and kept frozen at $-20^{\circ} \mathrm{C}$ for analyses of purine derivatives (PD), creatinine, total $\mathrm{N}, \mathrm{NH}_{3}-\mathrm{N}$, and urea $\mathrm{N}$ concentrations. Feces were collected in preweighed plastic-lined plywood boxes and mixed daily. A representative sample (2\%) was taken, stored at $-20^{\circ} \mathrm{C}$, and subsequently thawed, freeze-dried, and ground through a $1-\mathrm{mm}$ screen (Wiley mill) for chemical analysis.

\section{Ruminal Microbial N Outflow}

Preliminary results showed a lack of concordance between estimations of duodenal microbial nitrogen (MN) flow based on PD and purine bases (Martineau et al., 2005). This effect possibly resulted from unreliable purine: $\mathrm{N}$ ratios in reference bacteria isolated from the thawed, formolized duodenal digesta. Therefore, the ruminal MN outflow was determined from urinary excretion of PD according to the equations of Chen and Gomes (1992):

$$
\begin{gathered}
\mathrm{Y}(\mathrm{mmol} / \mathrm{d})=(0.85 \times \mathrm{X})+\left(0.385 \times \mathrm{BW}^{0.75}\right) \\
\mathrm{MN}(\mathrm{g} / \mathrm{d})=[70 /(0.116 \times 0.83 \times 1000)] \times \mathrm{X}=0.727 \times \mathrm{X}
\end{gathered}
$$

where $\mathrm{X}$ and $\mathrm{Y}$ are the absorption and the excretion of $\mathrm{PD}(\mathrm{mmol} / \mathrm{d})$, respectively. Those equations assume that the daily excretion of PD in milk is $1 \mathrm{mmol} / \mathrm{kg}$ of milk produced, the $\mathrm{N}$ content of purines is $70 \mathrm{mg} /$ mmol, the ratio of purine $\mathrm{N}$ to total $\mathrm{N}$ in mixed rumen microbes is 0.116 , the endogenous contribution to urinary $\mathrm{PD}$ excretion is $0.385 \times \mathrm{BW}^{0.75} \mathrm{mmol} / \mathrm{d}$, the true intestinal digestibility of microbial purines is $83 \%$, and the recovery of absorbed purines as urinary PD is $85 \%$.

\section{WB Protein Metabolism}

A polyvinyl catheter was inserted in both jugular veins on d 25 of each period. On d 26, the $\mathrm{CO}_{2}$ entry rate (CER) was measured using a 6-h (from 0900 to
$1500 \mathrm{~h}$ ) primed ( $1.4 \mathrm{mmol})$ continuous jugular infusion of $\mathrm{NaH}^{13} \mathrm{CO}_{3}(1.0 \mathrm{mmol} / \mathrm{h} ; 99$ atom \%; Cambridge Isotope Laboratories, Andover, MA). Blood samples from the contralateral jugular vein were collected into heparinized syringes in the hour before the infusion to determine $\left[{ }^{13} \mathrm{C}\right]$ natural abundance in $\mathrm{CO}_{2}$, followed by 6 hourly samples, starting $1 \mathrm{~h}$ after the initiation of the infusion. Immediately after collection, two 1$\mathrm{mL}$ blood aliquots were injected into evacuated Vacutainers (Becton Dickinson, Franklin Lakes, NJ) containing $1 \mathrm{~mL}$ of frozen lactic acid, snap-frozen in liquid $\mathrm{N}$ (Read et al., 1984), and kept frozen at $-20^{\circ} \mathrm{C}$ until analyzed for determination of the isotopic enrichment (IE).

On d 27 of each period, the Leu irreversible loss rate (ILR) was used to estimate WB protein metabolism or protein turnover using a 6-h (from 0900 to $1500 \mathrm{~h}$ ) primed $(2.4 \mathrm{mmol})$ continuous jugular infusion of $\mathrm{L}-$ $\left[1-{ }^{13} \mathrm{C}\right] \mathrm{Leu}(2.4 \mathrm{mmol} / \mathrm{h} ; 99$ atom \%; Cambridge Isotope Laboratories). Blood samples from the contralateral jugular vein were collected into heparinized syringes in the hour before the infusion to determine $\left[{ }^{13} \mathrm{C}\right]$ natural abundance in Leu, 4-methyl 2-oxopentanoate (MOP) and $\mathrm{CO}_{2}$, followed by 6 hourly samples, starting $1 \mathrm{~h}$ after the initiation of the infusion. Immediately after collection, two 1-mL blood aliquots were treated and stored as previously described. The remaining blood was centrifuged and plasma was stored at $-20^{\circ} \mathrm{C}$ for the determination of $\left[{ }^{13} \mathrm{C}\right] \mathrm{IE}$ of Leu and MOP.

In all equations of protein turnover, WB ILR and infusion rates are expressed in millimoles per hour and IE in atom percent excess. Tracer refers to $\left[{ }^{13} \mathrm{C}\right]$ Leu or $\left[{ }^{13} \mathrm{C}\right]$ bicarbonate and tracee is the unlabeled Leu and bicarbonate. Whole-body Leu ILR or CER was calculated as follows:

$$
\text { WB-ILR } \text { tracee }_{\text {or }} \mathrm{CER}_{\text {tracee }}=\left[\left(\mathrm{IE}_{\text {inf }} / \mathrm{IE}_{\mathrm{p}}\right)-1\right] \times \operatorname{Inf},
$$

where $\mathrm{IE}_{\text {inf }}$ and $\mathrm{IE}_{\mathrm{p}}$ are the $\left[{ }^{13} \mathrm{C}\right] \mathrm{IE}$ of the infusate and the mean $\left[{ }^{13} \mathrm{C}\right] \mathrm{IE}$ of venous plasma $\mathrm{CO}_{2}$, MOP, or Leu, respectively, and Inf is the infusion rate of the labeled bicarbonate (d 26) or Leu (d 27). The mean enrichment was the arithmetic mean of the 6 hourly samples taken under plateau conditions during the infusion. Leucine tracer oxidation $(\mathrm{mmol} / \mathrm{h})$ was calculated as:

$$
\mathrm{Leu}_{\text {tracer }} \text { oxidation }=\mathrm{CER} \times \mathrm{IE}_{\mathrm{CO}_{2} \text {-Leu }} / 100,
$$

where CER is the $\mathrm{CO}_{2}$ entry rate ( $\left.\mathrm{d} 26\right), \mathrm{IE}_{\mathrm{CO}_{2} \text {-Leu }}$ is the mean venous plasma $\left[{ }^{13} \mathrm{C}\right] \mathrm{IE}$ of $\mathrm{CO}_{2}$ measured during the infusion of labeled Leu (d 27), assuming that CER production on $d 26$ is the same as $d 27$. 
The fractional rate of oxidation (FO) of Leu (tracer + tracee) was calculated as:

$$
\mathrm{FO}_{\text {tracer }}+\text { tracee }=\mathrm{Leu}_{\text {tracer }} \text { oxidation } /\left(\operatorname{Inf}_{\text {Leu }} \times \mathrm{IE}_{\text {inf }}\right),
$$

where $\operatorname{Inf}_{\text {Leu }}$ is the infusion rate of labeled Leu and $\mathrm{IE}_{\text {inf }}$ is the $\left[{ }^{13} \mathrm{C}\right] \mathrm{IE}$ of the infusate. It was assumed that tracee and tracer were metabolized similarly and that the equivalent of the infused dose was in excess and was oxidized (Lobley et al., 2003); therefore, Leutracee oxidation (LO) was calculated as:

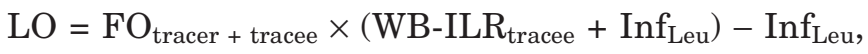

where $\operatorname{Inf}_{\text {Leu }}$ is the infusion rate of Leu (d 27). The FO of Leu (tracee) was calculated as:

$$
\mathrm{FO}_{\text {tracee }}=\mathrm{LO} / \mathrm{WB}-\mathrm{LR}_{\text {tracee }}
$$

Leucine used for protein synthesis was calculated as the difference between WB-ILR $\mathrm{L}_{\text {tracee }}$ of Leu and LO, using MOP as representative of the precursor pool. Leucine used for protein synthesis was further partitioned into Leu secreted in milk protein or used for nonmilk protein. Leucine secreted in milk or retained $(\mathrm{mmol} / \mathrm{h})$ was determined during the total collection of feces and urine, assuming constant fractions of 98 $\mathrm{g}$ of Leu/kg of milk protein secreted (Swaisgood, 1995) and $63 \mathrm{~g}$ of Leu/kg of synthesized tissue protein (Lobley et al., 1980). The same constant fractions were used to estimate protein synthesis on a kilogram per day basis. Leucine returning to the compartment from protein breakdown was calculated as the difference between Leu used for protein synthesis minus Leu in milk and retained in tissues. Leucine absorbed was calculated by the difference between WB ILR and WB protein breakdown.

\section{Blood Metabolites}

Six heparinized blood samples were taken hourly (from 1000 to $1500 \mathrm{~h}$ ) on d 27 to determine plasma urea N, glucose, and AA concentrations. For AA analyses, $0.2 \mathrm{~g}$ of an internal standard solution was added to $1 \mathrm{~g}$ of plasma and samples were kept frozen at $-80^{\circ} \mathrm{C}$ until analyses. The internal standard solution was prepared with labeled AA diluted in water to the following concentrations $(\mu M)$ : DL-His $-\alpha-{ }^{15} \mathrm{~N}(155)$, L-Ile${ }^{15} \mathrm{~N}$ (733), L-Leu- $1-{ }^{13} \mathrm{C}(876)$, DL-Lys- $\alpha-{ }^{15} \mathrm{~N}-2 \mathrm{HCl}$ (313), DL-Met- $1-{ }^{13} \mathrm{C}(106)$, L-Phe- $1-{ }^{13} \mathrm{C}(238)$, L-Thr- ${ }^{15} \mathrm{~N}$ (475), L-Trp- $1-{ }^{13} \mathrm{C}(84)$, L-Val- ${ }^{15} \mathrm{~N}$ (832), L-Ala- $1-{ }^{13} \mathrm{C}(1,082)$, L-Gln- $1-{ }^{13} \mathrm{C} \quad$ (905), L-Glu-1- ${ }^{13} \mathrm{C} \quad(292), \quad$ Gly- $1-{ }^{13} \mathrm{C}$ (1,240), L-Ser- $1-{ }^{13} \mathrm{C}$ (478), and L-Tyr- ${ }^{15} \mathrm{~N}$ (260). Labeled AA (95 to 99 atom \%) were supplied by CDN Isotopes
Inc. (Montreal, QC, Canada) for His, Leu, Lys, Met, and Phe; by Cambridge Isotope Laboratories for Ile, Thr, Trp, Ala, Gln, Glu, Gly, Ser, and Tyr; and by Isotec Inc. (Miamisburg, OH) for Val.

\section{Chemical Analyses}

Analytical DM content was determined by oven-drying at $135^{\circ} \mathrm{C}$ for $2 \mathrm{~h}$. Subsamples were ashed at $550^{\circ} \mathrm{C}$ for $12 \mathrm{~h}$ in a muffle furnace. The total $\mathrm{N}$ content was determined by thermal conductivity (Leco model FP428 Nitrogen Determinator; Leco, St. Joseph, MI) and $\mathrm{CP}$ was calculated as $\mathrm{N} \times 6.25$ (or 6.38 for milk). Soluble protein and NPN were determined after solubility in a borate-phosphate buffer at $39^{\circ} \mathrm{C}$ during $1 \mathrm{~h}$ and precipitation of soluble protein supernatant with TCA (0.8 M; Roe et al., 1990). The concentration of NDF was determined as described by van Soest et al. (1991) using sodium sulfite and heat-stable $\alpha$-amylase. The $\mathrm{ADF}$ content was determined as described by Robertson and Van Soest (1981). The NDF and ADF procedures were done using an Ankom ${ }^{200}$ fiber analyzer (Ankom Technology). Soluble carbohydrates were assayed by the phenol-sulfuric acid method (Dubois et al., 1956). Concentrations of AA were measured with an AA analyzer (Biochrom 20; Amersham Pharmacia Biotech, Piscataway, NJ) after a 24-h acid hydrolysis with $6 \mathrm{~N}$ phenol- $\mathrm{HCl}$ at $110^{\circ} \mathrm{C}$. A performic acid oxidation step was done for Met and Cys prior to acid hydrolysis (method 994.12; AOAC, 2000). Concentration of $\mathrm{NH}_{3}-\mathrm{N}$ was analyzed using the indophenol-blue method (Novozamsky et al., 1974). Concentration of VFA was determined with an HPLC Gold System (Beckman Instruments, San Ramon, CA). Chromium was extracted (Siddons et al., 1985) and measured by atomic absorption with an air-acetylene flame.

The concentrations of $\mathrm{N}$ in acidified urine samples, in NPN filtrate, and in NDF and ADF residues were determined by micro-Kjeldahl analysis (method 955.04; AOAC, 1990). Purine derivatives and creatinine were determined according to the procedure of Balcells et al. (1992) with a Beckman System Gold chromatograph (Beckman Instruments, Fullerton, CA).

Milk fat concentration was measured according to the Röse-Gottlieb procedure (method 905.02; AOAC, 1990). Contents of DM and ash were measured with a thermogravimetric analyzer (model TGA-601; Leco Corp.). Milk lactose was calculated by the difference between the amount of OM and CP plus fat. Casein $\mathrm{N}$ was calculated by the difference after precipitation of milk proteins at $\mathrm{pH} 4.6$ with $10 \%$ acetic acid. Urea $\mathrm{N}$ was determined colorimetrically on a Technicon autoanalyzer (Technicon Instruments, Tarrytown, NY). 
The blood samples frozen on lactic acid were thawed immediately prior to analysis and reacted at room temperature. The liberated $\mathrm{CO}_{2}$ was analyzed for $\left[{ }^{13} \mathrm{C}\right]$ IE as mass-to-charge ions $44,45,46$ on a triple collector isotopic ratio mass spectrometer (Sira 12; VG Masslab, Manchester, UK). Results were pooled by cow. The plasma samples for determination of the IE free Leu and its oxo-acid (MOP) were deproteinized with sulfosalicylic acid and desalted on AG-50 $\mathrm{H}^{+}$ resin. The freeze-dried eluate was derivatized with $N$ (tert-butyldimethysilyl)- $N$-methyltrifluoroacetamide:acetronile (1:1) to form the $N$-(tert-butyldimethyl) AA derivative. The IE was determined with mass-to-charge ions 302, 303 for Leu and 259, 260 for MOP by GC-MS (model GC6890-MS5973; Agilent Technologies, Wilmington, DE), as described by Calder and Smith (1988). Isotopic enrichments for Leu, $\mathrm{MOP}$, and $\mathrm{CO}_{2}$ were corrected for background abundance, expressed as atom percent excess, and pooled by cow.

Plasma AA on hourly samples were determined by isotopic dilution (model GC6890-MS5973; Agilent Technologies; Calder et al., 1999) and pooled by cow. Plasma glucose on pooled hourly samples was measured by the Roche Hitachi glucose oxidase method (Roche Diagnostics, Mannheim, Germany).

\section{Statistical Analyses}

Because of the loss of 2 cows due to problems unrelated to the treatments, the statistical analysis was performed as a $3 \times 4$ Youden square (Cochran and Cox, 1957). The period 1 data from another cow could not be used because the cow refused to eat the chopped hay. Data were analyzed using the MIXED procedure of SAS (SAS Institute, 2000) according to the model

$$
\mathrm{Y}_{i j k}=\mu+\mathrm{a}_{i}+\beta_{j}+\tau_{k}+\mathrm{e}_{i j k},
$$

where $\mathrm{Y}_{i j k}$ is the response variable, $\mu$ is the overall mean, $\mathrm{a}_{i}$ is the random effect of cow $i(1, \ldots, 4), \beta_{j}$ is the effect of period $j(1,2,3), \tau_{k}$ is the effect of treatment $k(1,2,3)$, and $\mathrm{e}_{i j k}$ is the residual error. For the statistical analysis of ruminal fermentation characteristics and plasma urea $\mathrm{N}$, sampling time and sampling time $\times$ treatment were added to the model and analyzed as repeated measures using PROC MIXED. Autoregressive order 1 and compound symmetry (homogeneous and heterogeneous) were tested as covariance structures and the covariance structure with the least Akaike's information criterion was retained in the final model. Sums of squares for treatment were separated into single degree of freedom preplanned orthogonal contrasts: hay vs. silages, and formic vs. inoc.
Results are reported as least squares means \pm standard errors of the means. Significance was declared at $P \leq 0.05$ and a trend at $P \leq 0.10$.

\section{RESULTS AND DISCUSSION}

\section{Composition of Forages}

The forages had contrasting contents of soluble protein and WSC (Table 2). The preservation of WSC is a prominent feature of hays and of restrictively fermented silages as opposed to extensively fermented silages in which WSC are fermented into lactic acid and VFA (McDonald et al., 1991). Significant losses of Arg and Trp were apparent in the extensively fermented silage, as previously reported by Anderson (1983). The extensively fermented silage contained twice the amount of fermentation acids and more ammonia $\mathrm{N}$ than the restrictively fermented silage, thus reflecting a greater extent of fermentation and proteolysis (McDonald et al., 1991).

\section{Ruminal Fermentation Characteristics}

Compared with formic, inoc reduced $(P<0.03$; Table 3) ruminal $\mathrm{pH}$. This effect was related to the greater VFA content, because $\mathrm{pH}$ and total VFA were negatively correlated $(\mathrm{r}=-0.82 ; P<0.01)$. Ruminal $\mathrm{NH}_{3}-\mathrm{N}$ paralleled the concentration of the rapidly degradable protein fraction (fraction a, $\%$ of $\mathrm{CP}$ ), as determined in a parallel in situ study using the same forages (Martineau et al., 2006). The lower $(P<0.01)$ ruminal $\mathrm{NH}_{3}$ $\mathrm{N}$ observed with hay than with silages is in agreement with the findings of Shingfield et al. (2002), whereas the reduced $(P=0.04)$ ruminal $\mathrm{NH}_{3}-\mathrm{N}$ with restrictively fermented silage, compared with extensively fermented silage, is in accordance with the findings of Keady et al. (1995). Results suggest that haying and restricting fermentation in silage decreased the degradation of $\mathrm{N}$ in the rumen or increased the uptake of degraded $\mathrm{N}$ by ruminal microbes, because silage VFA (Chamberlain, 1987) and lactic acid (Jaakkola and Huhtanen, 1992) are poor ATP substrates for ruminal microbes compared with WSC.

The molar proportion of propionate was lower for hay than silages $(P=0.03)$ and for formic vs. inoc $(P=$ 0.07). However, the molar proportion of acetate and the ratio of acetate to propionate were greater for hay than silages $(P=0.02)$ and for formic vs. inoc $(P=$ 0.04). Ruminal fermentation patterns with relatively high proportions of lipogenic short-chain fatty acids and small proportions of propionate are typical of diets based on hay compared with silage (Vagnoni and Broderick, 1997; Shingfield et al., 2002), or based on restrictively fermented silage in comparison with extensively 
Table 3. Effects of the method of conservation of timothy on ruminal fermentation characteristics, milk production, and milk composition of dairy cows

\begin{tabular}{|c|c|c|c|c|c|c|}
\hline \multirow[b]{2}{*}{ Item } & \multicolumn{3}{|c|}{ Conservation method $^{1}$} & \multirow[b]{2}{*}{ SEM } & \multicolumn{2}{|c|}{ Contrast ${ }^{2} P$-value } \\
\hline & Hay & Formic & Inoc & & $\mathrm{H}$ vs. $\mathrm{F}+\mathrm{I}$ & F vs. I \\
\hline $\mathrm{pH}$ & 6.3 & 6.5 & 6.3 & 0.1 & 0.43 & 0.03 \\
\hline $\mathrm{NH}_{3}-\mathrm{N}, \mathrm{mg} / \mathrm{dL}$ & 8.0 & 9.6 & 11.0 & 0.7 & $<0.01$ & 0.04 \\
\hline Total VFA, $\mathrm{m} M$ & 123.1 & 120.3 & 129.3 & 3.5 & 0.68 & 0.08 \\
\hline \multicolumn{7}{|l|}{ VFA, mol/100 mol } \\
\hline Acetate (A) & 69.4 & 68.8 & 66.8 & 0.3 & $<0.01$ & $<0.01$ \\
\hline Propionate $(\mathrm{P})$ & 15.3 & 16.3 & 17.7 & 0.5 & 0.03 & 0.07 \\
\hline Butyrate & 10.2 & 9.9 & 10.1 & 0.5 & 0.73 & 0.73 \\
\hline $\mathrm{A}: \mathrm{P}$ & 4.55 & 4.23 & 3.79 & 0.14 & 0.02 & 0.04 \\
\hline Milk production, $\mathrm{kg} / \mathrm{d}$ & 23.9 & 24.4 & 22.4 & 1.9 & 0.71 & 0.21 \\
\hline $4 \% \mathrm{FCM}^{3} \mathrm{~kg} / \mathrm{d}$ & 23.1 & 23.0 & 22.8 & 2.6 & 0.81 & 0.85 \\
\hline \multicolumn{7}{|l|}{ Milk composition, \% } \\
\hline Fat & 3.77 & 3.59 & 4.00 & 0.27 & 0.80 & 0.02 \\
\hline Protein & 2.92 & 2.90 & 2.97 & 0.10 & 0.93 & 0.61 \\
\hline Lactose & 4.79 & 4.89 & 4.83 & 0.09 & 0.50 & 0.53 \\
\hline $\mathrm{CN} \mathrm{N}, \%$ of total $\mathrm{N}$ & 89.2 & 89.1 & 89.3 & 1.2 & 0.95 & 0.65 \\
\hline MUN, mg/dL & 7.20 & 6.69 & 8.94 & 0.64 & 0.21 & 0.01 \\
\hline \multicolumn{7}{|l|}{ Milk yield, $\mathrm{kg} / \mathrm{d}$} \\
\hline Fat & 0.91 & 0.88 & 0.92 & 0.13 & 0.89 & 0.32 \\
\hline Protein & 0.69 & 0.71 & 0.66 & 0.07 & 0.90 & 0.17 \\
\hline Lactose & 1.15 & 1.19 & 1.10 & 0.11 & 0.93 & 0.33 \\
\hline
\end{tabular}

\footnotetext{
${ }^{1}$ Hay $=$ haying; formic $=$ restrictively fermented silage; inoc $=$ extensively fermented silage; least squares means with SEM given for $\mathrm{n}=3$.

${ }^{2}$ Contrast: $\mathrm{H}$ vs. $\mathrm{F}+\mathrm{I}$ = hay vs. silages; $\mathrm{F}$ vs. $\mathrm{I}=$ formic vs. inoc.

${ }^{3} 4 \% \mathrm{FCM}=0.4 \times(\mathrm{milk}, \mathrm{kg} / \mathrm{d})+15.0 \times($ fat, $\mathrm{kg} / \mathrm{d})$.
}

fermented silage (van Vuuren et al., 1995; Huhtanen, 1998). Those changes in the ruminal fermentation pattern were previously linked to differences in WSC (van Vuuren et al., 1995) and lactic acid (Martin et al., 1994; van Vuuren et al., 1995) concentrations in the forage.

\section{Milk Production and Milk Composition}

Production of milk and 4\% FCM averaged 23.4 and $23.0 \mathrm{~kg} / \mathrm{d}$, respectively, and was not affected by the method of conservation of timothy (Table 3). Milk fat concentration was lower $(P=0.02)$ with formic than with inoc, but milk fat yield was unaffected. van $\mathrm{Vu}$ uren et al. (1995) reported that feeding silages of restricted fermentation, as compared with high-lactate silages, consistently increased the milk fat content, likely because silages rich in WSC favor a rumen fermentation pattern rich in acetate, butyrate, or both, thereby changing the lipogenic:glucogenic VFA ratio. In our study, the milk fat content was lower with formic than with inoc possibly due to a dilution effect, because milk production was numerically greater. The method of conservation of timothy did not affect milk protein concentration and yield.

\section{Digestion of OM and NDF}

The recovery rates of $\mathrm{Cr}$ were not statistically different among treatments (Table 4) and the duodenal DM flows were based on mean individual fecal excretion of $\mathrm{Cr}$ during the total collection of feces. Intakes of DM averaged $17.1 \mathrm{~kg} / \mathrm{d}$ and were unaffected by treatment. The disappearance of digestible true OM before the small intestine tended $(P=0.09)$ to be lower with hay than with silages, whereas the apparent total tract digestibility was unaffected by treatments, suggesting a greater extent of OM digestion in the intestine with hay than with silages.

Intake of NDF was higher $(P=0.04)$ with hay than with silages without affecting the apparent total tract digestibility, because the fecal flow of NDF was concomitantly increased $(P=0.02)$. The disappearance of digestible NDF before the small intestine was higher $(P=0.02)$ with formic compared with inoc, suggesting that the hydrolysis of hemicellulose during ensiling was less severe, thereby increasing the digestibility of remaining NDF (McDonald et al., 1991).

\section{Digestion of $\mathbf{N}$ and Efficiency of Microbial Synthesis}

The lower $\mathrm{CP}$ (or $\mathrm{N}$ ) percentage in hay resulted in lower $\mathrm{N}$ intake because DMI $(17.1 \mathrm{~kg} / \mathrm{d})$ were not different across treatments (Table 5). Expressed as a proportion of $\mathrm{N}$ intake, total tract apparent digestibility of $\mathrm{N}$ was lower ( 63.8 vs. $68.2 \% ; P=0.02$ ) with hay than with silages because the lower $\mathrm{N}$ intake was not followed by a reduced fecal $\mathrm{N}$ output. Total tract ap- 
Table 4. Effects of the method of conservation of timothy on OM and NDF digestion in dairy cows

\begin{tabular}{|c|c|c|c|c|c|c|}
\hline \multirow[b]{2}{*}{ Item } & \multicolumn{3}{|c|}{ Conservation method ${ }^{1}$} & \multirow[b]{2}{*}{ SEM } & \multicolumn{2}{|c|}{ Contrast, ${ }^{2} P$-value } \\
\hline & Hay & Formic & Inoc & & $\mathrm{H}$ vs. $\mathrm{F}+\mathrm{I}$ & F vs. I \\
\hline Chromium recovery rate, $\%$ & 90.3 & 84.7 & 84.7 & 2.5 & 0.15 & 0.99 \\
\hline DMI, kg/d & 17.3 & 17.0 & 17.0 & 1.6 & 0.45 & 0.91 \\
\hline \multicolumn{7}{|l|}{ OM flows, $\mathrm{kg} / \mathrm{d}$} \\
\hline In feed & 16.3 & 15.9 & 15.8 & 1.5 & 0.28 & 0.81 \\
\hline At duodenum & 9.2 & 8.3 & 8.5 & 0.8 & 0.29 & 0.71 \\
\hline In feces & 4.6 & 4.4 & 4.1 & 0.4 & 0.13 & 0.15 \\
\hline \multicolumn{7}{|l|}{$\mathrm{OM}$ apparent digestibility, $\%$} \\
\hline In the rumen & 44.8 & 47.6 & 46.5 & 2.9 & 0.53 & 0.77 \\
\hline In the rumen, true ${ }^{3}$ & 54.5 & 61.5 & 59.0 & 3.5 & 0.11 & 0.42 \\
\hline In the intestine ${ }^{4}$ & 49.8 & 47.1 & 51.8 & 2.2 & 0.87 & 0.12 \\
\hline In the total tract & 72.6 & 72.4 & 74.3 & 1.0 & 0.54 & 0.21 \\
\hline \multicolumn{7}{|l|}{ OM disappearance before small intestine,$^{5} \%$} \\
\hline Apparent & 61.7 & 65.7 & 62.4 & 3.5 & 0.57 & 0.47 \\
\hline True ${ }^{3} \%$ & 75.5 & 84.9 & 79.3 & 4.2 & 0.09 & 0.13 \\
\hline \multicolumn{7}{|l|}{ NDF flows, kg/d } \\
\hline In feed & 7.2 & 6.4 & 6.0 & 0.6 & 0.04 & 0.26 \\
\hline At duodenum & 2.4 & 2.3 & 2.4 & 0.2 & 0.53 & 0.50 \\
\hline In feces & 2.7 & 2.5 & 2.2 & 0.2 & 0.02 & 0.02 \\
\hline \multicolumn{7}{|l|}{ NDF digestibility, $\%$} \\
\hline In the rumen & 66.9 & 64.8 & 61.1 & 2.1 & 0.21 & 0.26 \\
\hline In the total tract & 63.3 & 60.6 & 64.3 & 1.8 & 0.70 & 0.19 \\
\hline NDF disappearance before small intestine ${ }^{5} \%$ & 1.06 & 1.07 & 0.95 & 0.03 & 0.14 & 0.02 \\
\hline
\end{tabular}

parent $\mathrm{N}$ digestibility is often reduced at low $\mathrm{N}$ intake compared with higher $\mathrm{N}$ intake because of similar endogenous $\mathrm{N}$ secretions in feces. Secretion of milk $\mathrm{N}$ (as a percentage of $\mathrm{N}$ intake) was greater $(P \leq 0.04)$ with hay compared with silages, and with formic compared with inoc. Comparison between hay and silages should take into account a lower CP intake for cows fed hay. Nitrogen excreted in urine was lower $(P=$ 0.01 ) with hay than with silages and with formic compared with inoc. However, as a proportion of $\mathrm{N}$ intake, only $\mathrm{N}$ excreted in urine tended $(P=0.09)$ to be lower with formic than with inoc. Approximately $59 \%$ of urinary $\mathrm{N}$ losses were in the form of urea $\mathrm{N}$, and this proportion tended (57.3 vs. $61.1 \% ; \mathrm{SEM}=1.3 ; P=$ 0.07 ) to be lower with formic than with inoc. Overall, $\mathrm{N}$ balance results suggest that cows fed the silages were producing milk at maximal capacity, and that the excess dietary $\mathrm{N}$ was either retained or excreted to urine. By contrast, even though $\mathrm{N}$ intake was lower with the hay diet, the available absorbed $\mathrm{N}$ appeared sufficient, so the cows did not need to store "excess" $\mathrm{N}$ and urine excretion was normal.

Despite the $14 \%$ lower $\mathrm{N}$ intake when hay was fed compared with silages, duodenal $\mathrm{N}$ flows were not different; therefore, a difference in milk protein yield would not be expected. The net amount of $\mathrm{N}$ recycled prior to the small intestine was higher $(P=0.02)$ and, conversely, the apparent digestibility of $\mathrm{N}$ in the rumen was lower $(P=0.01)$ with hay compared with silages, suggesting that more $\mathrm{N}$ was captured as $\mathrm{MN}$ or more feed $\mathrm{N}$ was undegraded when hay was fed. The disparity between the values of the apparent and the true digestibility in the rumen reflected the large net recycling of $\mathrm{N}$ to the rumen in our study. The lower proteolysis of hay during haying meant less soluble $\mathrm{N}$. In consequence, more insoluble $\mathrm{N}$ was present to pass through the rumen. On the other hand, the true digestibility of $\mathrm{N}$ in the rumen was similar between silages, suggesting that $\mathrm{N}$ degradability in the rumen was not affected by the method of conservation.

Efficiencies of MN synthesis were not affected by treatments (Table 5). In contrast to our results, Huhtanen et al. (1997) reported a $12 \%$ increase in efficiency of $\mathrm{MN}$ synthesis on restrictively fermented silage compared with extensively fermented silage. In their study, WSC contents of both silages were higher than the presently reported values, and WSC concentration of the restrictively fermented silage was nearly 3 -fold greater than that of the extensively fermented silage ( 17.7 vs. $6.8 \%$ of $\mathrm{DM}$ ), and therefore contrasted more than in our study. 
Table 5. Effects of the method of conservation of timothy on $\mathrm{N}$ digestion and microbial synthesis in dairy cows

\begin{tabular}{|c|c|c|c|c|c|c|}
\hline \multirow[b]{2}{*}{ Item } & \multicolumn{3}{|c|}{ Conservation method ${ }^{1}$} & \multirow[b]{2}{*}{ SEM } & \multicolumn{2}{|c|}{ Contrast, ${ }^{2} P$-value } \\
\hline & Hay & Formic & Inoc & & $\mathrm{H}$ vs. $\mathrm{F}+\mathrm{I}$ & F vs. I \\
\hline $\mathrm{N}$ intake, $\mathrm{g} / \mathrm{d}$ & 348 & 398 & 414 & 37 & 0.02 & 0.28 \\
\hline Feces & 127 & 127 & 133 & 13 & 0.59 & 0.39 \\
\hline Milk & 108 & 111 & 104 & 11 & 0.90 & 0.17 \\
\hline Urine & 93 & 101 & 116 & 9 & 0.01 & 0.01 \\
\hline $\mathrm{N}$ retained & 21 & 59 & 62 & 9 & 0.02 & 0.80 \\
\hline \multicolumn{7}{|l|}{$\%$ of $\mathrm{N}$ intake } \\
\hline Feces & 36.2 & 31.9 & 31.7 & 0.9 & 0.02 & 0.81 \\
\hline Milk & 30.9 & 28.2 & 24.7 & 0.8 & 0.02 & 0.04 \\
\hline Urine & 27.0 & 25.4 & 28.4 & 1.1 & 0.96 & 0.09 \\
\hline $\mathrm{N}$ retained & 5.9 & 14.4 & 15.2 & 1.9 & 0.03 & 0.74 \\
\hline \multicolumn{7}{|l|}{ Duodenal flow, g/d } \\
\hline Total N & 403 & 387 & 400 & 42 & 0.51 & 0.41 \\
\hline $\mathrm{NH}_{3}-\mathrm{N}$ & 10 & 12 & 13 & 1 & 0.08 & 0.60 \\
\hline Microbial N & 187 & 248 & 230 & 50 & 0.16 & 0.57 \\
\hline Feed $\mathrm{N}^{3}$ & 171 & 93 & 124 & 29 & 0.10 & 0.34 \\
\hline Net $\mathrm{N}$ recycling before small intestine,${ }^{4} \mathrm{~g} / \mathrm{d}$ & 54 & -12 & -15 & 17 & 0.02 & 0.85 \\
\hline \multicolumn{7}{|l|}{$\mathrm{N}$ apparent digestibility, $\%$} \\
\hline In the rumen & -14.6 & 3.3 & 4.4 & 3.7 & 0.01 & 0.80 \\
\hline In the rumen, true ${ }^{5}$ & 51.7 & 75.7 & 68.5 & 8.6 & 0.06 & 0.40 \\
\hline In the intestine ${ }^{6}$ & 68.7 & 66.7 & 66.7 & 1.3 & 0.06 & 0.93 \\
\hline \multicolumn{7}{|l|}{ Efficiency of microbial synthesis } \\
\hline Microbial N/OMADR, ${ }^{7} \mathrm{~g} / \mathrm{kg}$ & 27.2 & 32.7 & 30.5 & 5.1 & 0.50 & 0.74 \\
\hline Microbial N/OMTDR, ${ }^{7} \mathrm{~g} / \mathrm{kg}$ & 21.8 & 25.2 & 23.4 & 3.1 & 0.53 & 0.68 \\
\hline Microbial N/N intake, g/g & 0.54 & 0.61 & 0.53 & 0.08 & 0.65 & 0.30 \\
\hline
\end{tabular}

${ }^{1}$ Hay = haying; formic $=$ restrictively fermented silage; inoc $=$ extensively fermented silage; least squares means with SEM given for $\mathrm{n}=3$.

${ }^{2}$ Contrast: $\mathrm{H}$ vs. $\mathrm{F}+\mathrm{I}=$ hay vs. silages; $\mathrm{F}$ vs. $\mathrm{I}=$ formic vs. inoc.

${ }^{3}$ Total $\mathrm{N}-\left(\mathrm{NH}_{3}-\mathrm{N}+\right.$ microbial $\mathrm{N}+$ endogenous $\left.\mathrm{N}\right)$, where endogenous $\mathrm{N}(\mathrm{g} / \mathrm{d})=1.9 \times \mathrm{DMI}(\mathrm{kg} / \mathrm{d})(\mathrm{NRC}$, 2001).

${ }^{4}$ Total $\mathrm{N}$ flow at duodenum minus intake of $\mathrm{N}$.

${ }^{5}$ Intake of $\mathrm{N}$ minus feed $\mathrm{N}$ flow at duodenum divided by intake of $\mathrm{N}$.

${ }^{6}$ Duodenal flow minus fecal flow divided by duodenal flow.

${ }^{7} \mathrm{OM}$ apparently (OMADR) or truly (OMTDR) digested in the rumen.

\section{WB Protein Metabolism}

Leucine kinetics were unaffected by treatments except for estimation of absorbed Leu, which was higher $(P=0.03)$ with formic than with inoc (Table 6). The CER averaged $14.0 \mathrm{~mol} / \mathrm{h}$ and was unaffected by treatments (SEM = 1.5; data not shown). Whole-body ILR of Leu was similar to values reported earlier in dairy cows by Bequette et al. (1996), Lapierre et al. (2002), and Raggio et al. (2006). Using MOP IE rather than Leu IE as representative of the precursor pool increased ILR by $31 \%$. Because MOP is formed intracellularly from deamination of Leu arising from plasma as well as from protein breakdown, MOP released in the plasma has a lower IE than plasma Leu.

The FO averaged $10.9 \%$, being in the low range of previous reports (Lapierre et al., 2002; Raggio et al., 2006 ), which was probably linked to the low protein supply in the present study. Leucine used for protein synthesis yielded an estimated WB protein synthesis of $4.3 \mathrm{~kg} / \mathrm{d}(\mathrm{SEM}=0.7 ; P=0.65)$, of which $687 \mathrm{~g} / \mathrm{d}$ was secreted as milk protein, indicating the high protein turnover in lactating dairy cows. Estimated Leu absorbed was 116,136 , and $114 \mathrm{~g} / \mathrm{d}$ or 76,109 , and $87 \%$ of Leu apparently digested for hay, formic, and inoc, respectively (Table 7 ).

\section{AA Flows and Digestion}

Intakes of essential AA (EAA; except Arg because of its greater content with hay) and branched-chain AA (BCAA) were, on average, 17\% lower $(P \leq 0.05$; data not shown) with hay than with silages. However, duodenal flow of AA was unaffected by treatments (data not shown). The duodenal profile of EAA closely matched that predicted by NRC (2001), except for His, which was 2 -fold greater (7.8\% of EAA) than the flow predicted by NRC (2001). Such discrepancies are difficult to explain because microbial (approximately $4 \%$ of EAA; NRC, 2001) and endogenous proteins (5.2\% of EAA in ruminal epithelial cells; Larsen et al., 2000) 
Table 6. Effects of the method of conservation of timothy on whole-body Leu kinetics in dairy cows

\begin{tabular}{lrrrrrrr}
\hline & \multicolumn{3}{c}{ Conservation method } & & \multicolumn{2}{c}{ Contrast, $^{2} P$-value } \\
\cline { 2 - 4 } Leucine, mmol/h & Hay & Formic & Inoc & SEM & H vs. F + I & F vs. I \\
\hline ILR MOP $^{3}$ & 102.2 & 111.1 & 102.1 & 15.9 & 0.51 & 0.23 \\
ILR Leu $^{3}$ & 84.3 & 78.6 & 78.2 & 6.5 & 0.12 & 0.90 \\
Fractional rate of oxidation, $^{4} \%$ & 13.0 & 11.5 & 8.2 & 2.0 & 0.19 & 0.19 \\
Oxidation $^{4}$ & 13.4 & 13.8 & 8.0 & 3.6 & 0.45 & 0.15 \\
Used for protein synthesis $^{4}$ & 89.6 & 97.3 & 94.2 & 13.9 & 0.44 & 0.69 \\
Secreted in milk protein $_{\text {Used in nonmilk protein }}$ & 21.5 & 22.1 & 20.6 & 2.1 & 0.90 & 0.17 \\
From protein breakdown $^{4}$ & 68.1 & 75.3 & 73.5 & 12.1 & 0.41 & 0.81 \\
Absorbed $^{4}$ & 65.6 & 67.9 & 65.8 & 11.8 & 0.84 & 0.76 \\
\hline
\end{tabular}

${ }^{1}$ Hay = haying; formic $=$ restrictively fermented silage; inoc $=$ extensively fermented silage; least squares means with SEM given for $\mathrm{n}=3$.

${ }^{2}$ Contrast: $\mathrm{H}$ vs. $\mathrm{F}+\mathrm{I}$ = hay vs. silages; $\mathrm{F}$ vs. $\mathrm{I}=$ formic vs. inoc.

${ }^{3}$ Irreversible loss rate $\left(\mathrm{ILR}_{\text {tracee }}\right)$ calculated with the jugular enrichment of 4-methyl 2-oxopentanoate (MOP) or Leu as representative of the precursor pool.

${ }^{4}$ Estimated using the isotopic enrichment of MOP as representative of the precursor pool.

are not particularly rich in His. Fecal flow of EAA was unaffected by treatments; however, the proportion of fecal total AA as EAA was lower (48.7 vs. $49.2 \%$; SEM = $0.2 ; P=0.01)$ with hay compared with silages. The apparent intestinal digestibilities of EAA, non-EAA, BCAA, and total AA averaged 75,72 , and $74 \%$ for hay, formic, and inoc, respectively, and tended $(P \leq 0.08)$ to be higher for hay compared with silages and lower with formic than with inoc. The apparent intestinal digestibilities ranged from $67 \%$ for Met to $78 \%$ for His.
The flows of digestible EAA to the small intestine calculated using NRC (2001) were 637, 718, and 750 $\mathrm{g} / \mathrm{d}$ for hay, formic, and inoc, respectively, whereas the measured amounts of apparently digested EAA were 749,660 , and 699 for hay, formic, and inoc, respectively (Table 7). The discrepancy between the NRC (2001) prediction and our result for hay is likely because NRC (2001) does not account for recycled N captured as MN when the RDP supply is deficient, thereby leading to MP being underestimated.

Table 7. Effects of the method of conservation of timothy on AA apparently digested in the intestine of dairy cows

\begin{tabular}{lrrrrrrr}
\hline & \multicolumn{3}{c}{${\text { Conservation } \text { method }^{1}}$} & & & \multicolumn{2}{c}{ Contrast, $^{2} P$-value } \\
\cline { 2 - 4 } \cline { 2 - 4 } AA, g/d & Hay & Formic & Inoc & SEM & H vs. F + I & F vs. I \\
\hline Arg & 75 & 71 & 74 & 8 & 0.46 & 0.51 \\
His & 64 & 55 & 56 & 8 & 0.30 & 0.83 \\
Ile & 71 & 68 & 73 & 9 & 0.59 & 0.01 \\
Leu & 153 & 125 & 131 & 15 & 0.13 & 0.66 \\
Lys & 108 & 96 & 103 & 12 & 0.23 & 0.27 \\
Met & 28 & 24 & 26 & 3 & 0.06 & 0.15 \\
Phe & 82 & 73 & 78 & 9 & 0.21 & 0.37 \\
Thr & 79 & 70 & 75 & 9 & 0.29 & 0.50 \\
Val & 91 & 78 & 83 & 9 & 0.17 & 0.45 \\
Ala & 102 & 93 & 94 & 11 & 0.17 & 0.81 \\
Asx & 167 & 151 & 160 & 18 & 0.25 & 0.37 \\
Cys & 24 & 20 & 21 & 3 & 0.19 & 0.68 \\
Glx & 228 & 198 & 207 & 25 & 0.15 & 0.55 \\
Gly & 89 & 98 & 93 & 7 & 0.22 & 0.37 \\
Pro & 74 & 64 & 67 & 8 & 0.22 & 0.64 \\
Ser & 80 & 70 & 71 & 8 & 0.21 & 0.84 \\
Essential AA & 749 & 660 & 699 & 81 & 0.19 & 0.44 \\
Nonessential AA & 764 & 694 & 714 & 76 & 0.23 & 0.66 \\
Branched-chain AA & 314 & 271 & 287 & 33 & 0.14 & 0.44 \\
Total AA & 1,513 & 1,354 & 1,413 & 156 & 0.21 & 0.53 \\
\hline
\end{tabular}

${ }^{1}$ Hay = haying; formic $=$ restrictively fermented silage; inoc = extensively fermented silage; least squares means with SEM given for $\mathrm{n}=3$.

${ }^{2}$ Contrast: $\mathrm{H}$ vs. $\mathrm{F}+\mathrm{I}$ = hay vs. silages; $\mathrm{F}$ vs. $\mathrm{I}$ = formic vs. inoc. 
Table 8. Effects of the method of conservation of timothy on concentrations of urea N, glucose, and AA in plasma of dairy cows

\begin{tabular}{|c|c|c|c|c|c|c|}
\hline \multirow[b]{2}{*}{ Item } & \multicolumn{3}{|c|}{ Conservation method ${ }^{1}$} & \multirow[b]{2}{*}{ SEM } & \multicolumn{2}{|c|}{ Contrast, ${ }^{2} P$-value } \\
\hline & Hay & Formic & Inoc & & $\mathrm{H}$ vs. $\mathrm{F}+\mathrm{I}$ & F vs. I \\
\hline Urea $\mathrm{N}, \mathrm{mg} / \mathrm{dL}$ & 6.8 & 7.6 & 8.5 & 0.9 & 0.28 & 0.40 \\
\hline Glucose, $\mathrm{m} M$ & 3.2 & 3.2 & 3.3 & 0.1 & 0.78 & 0.79 \\
\hline \multicolumn{7}{|l|}{$\mathrm{AA}, \mu M$} \\
\hline His & 25 & 20 & 19 & 4 & 0.15 & 0.72 \\
\hline Ile & 112 & 110 & 104 & 6 & 0.27 & 0.18 \\
\hline Leu & 141 & 134 & 129 & 6 & 0.12 & 0.34 \\
\hline Lys & 71 & 69 & 71 & 6 & 0.81 & 0.79 \\
\hline Met & 19 & 19 & 17 & 1 & 0.16 & 0.03 \\
\hline Phe & 40 & 36 & 36 & 1 & 0.11 & 0.93 \\
\hline Thr & 81 & 84 & 76 & 5 & 0.81 & 0.06 \\
\hline $\operatorname{Trp}$ & 50 & 54 & 48 & 3 & 0.73 & 0.08 \\
\hline Val & 198 & 190 & 168 & 7 & 0.11 & 0.09 \\
\hline Ala & 240 & 268 & 255 & 11 & 0.14 & 0.33 \\
\hline Gln & 235 & 252 & 272 & 6 & 0.01 & 0.03 \\
\hline Glu & 60 & 63 & 59 & 4 & 0.64 & 0.22 \\
\hline Gly & 259 & 274 & 303 & 15 & 0.16 & 0.18 \\
\hline Ser & 73 & 72 & 74 & 4 & 0.98 & 0.71 \\
\hline Tyr & 42 & 42 & 40 & 2 & 0.74 & 0.63 \\
\hline Essential AA (EAA) & 733 & 717 & 668 & 28 & 0.10 & 0.07 \\
\hline Nonessential AA & 906 & 971 & 1,004 & 16 & 0.02 & 0.20 \\
\hline Branched-chain AA & 448 & 434 & 401 & 18 & 0.11 & 0.10 \\
\hline Total AA (TAA) & 1,647 & 1,689 & 1,672 & 22 & 0.09 & 0.33 \\
\hline $\mathrm{EAA}, \%$ of TAA & 45 & 42 & 40 & 1 & 0.06 & 0.12 \\
\hline
\end{tabular}

\footnotetext{
${ }^{1}$ Hay $=$ haying; formic $=$ restrictively fermented silage; inoc $=$ extensively fermented silage; least squares means with SEM given for $\mathrm{n}=3$.

${ }^{2}$ Contrast: $\mathrm{H}$ vs. $\mathrm{F}+\mathrm{I}$ = hay vs. silages; F vs. I = formic vs. inoc.
}

\section{Blood Metabolites}

Plasma urea $\mathrm{N}$ was unaffected by treatments (Table 8), but was correlated with ruminal $\mathrm{NH}_{3}-\mathrm{N}$ ( $\mathrm{r}=0.66$; $P=0.03)$ and MUN $(\mathrm{r}=0.71 ; P=0.01)$. The proportion of plasma total AA as EAA tended $(P=0.06)$ to be greater with hay compared with silages because of a tendency for an increase $(P=0.10)$ in plasma EAA and a decrease $(P=0.02)$ in plasma non-EAA. Concentrations of all EAA, except Trp, were numerically greater with hay than with silages, whereas the concentration of Gln was lower $(P=0.01)$ and concentrations of Ala, Glu, and Gly were numerically lower with hay compared with silages. When comparing silage types, concentrations of EAA, BCAA, Met, Thr, Trp, and Val tended $(P \leq 0.10)$ to be higher with formic than with inoc, whereas the opposite was true for Gln $(P=0.03)$.

Miettinen and Huhtanen (1997) reported lower plasma glucose concentrations and markedly higher ratios of lipogenic to glucogenic ruminal VFA concentrations (Huhtanen et al., 1997) in cows fed a restrictively fermented silage compared with an extensively fermented silage. In our study, the ratio of ruminal acetate to propionate was increased by restricting silage fermentation (Table 3 ), but without a concomitant effect on plasma glucose concentrations (Table 7). The ratios of ruminal acetate to propionate were negatively correlated with plasma concentrations of Gln $(\mathrm{r}=-0.83 ; P<0.01)$ and Gly $(\mathrm{r}=-0.79 ; P<0.01)$, suggesting a possible use of Gln and Gly for gluconeogenesis. However, other glucogenic sources (e.g., glycerol, lactate, pyruvate) have not been assessed in this study.

\section{CONCLUSIONS}

In the conditions of the present study, both formic and inoc methods produced silages with good fermentation quality. Haying reduced feed protein degradation in the rumen, whereas this effect was not observed when restricting fermentation in the silage. Haying and restricting fermentation in silages resulted in a better $\mathrm{N}$ utilization, as indicated by lower ruminal ammonia, reduced urinary excretion of $\mathrm{N}$, and an increased efficiency of milk protein secretion (as a proportion of $\mathrm{N}$ intake). Haying and restricting fermentation in silages induced a lipogenic fermentation pattern in the rumen but did not affect the yield of milk components and concentration of plasma glucose.

\section{ACKNOWLEDGMENTS}

The authors gratefully thank L. Croteau, M. Léonard, S. Provencher, and J. Renaud for sample collec- 
tion and laboratory analyses. The statistical advice of S. Méthot and the surgical expertise of P. Dubreuil and M. Babkine are also gratefully acknowledged. The authors are grateful to A. Brito and D. Valkeners for their judicious advice and to the staff of the Dairy Centre for care of the animals. Appreciation is extended to Agriculture and Agri-Food Canada, to La Fédération des Producteurs de Lait du Québec and the Fonds de Recherche sur la Nature et les Technologies for their financial support. Lennoxville Research Centre contribution no. 950.

\section{REFERENCES}

Anderson, R. 1983. The effect of extended moist wilting and formic acid additive on the conservation as silage of two grasses differing in total nitrogen content. J. Sci. Food Agric. 34:808-818.

AOAC. 1990. Official Methods of Analysis. Vol. I and II. 15th ed. AOAC, Arlington, VA.

AOAC. 2000. Official Methods of Analysis. 17th ed. AOAC, Arlington, VA.

Balcells, J., J. A. Guada, J. M. Peiro, and D. S. Parker. 1992. Simultaneous determination of allantoin and oxypurines in biological fluids by high-performance liquid chromatography. J. Chromatogr. 575:153-157.

Bequette, B. J., J. A. Metcalf, D. Wray-Cahen, F. R. Backwell, J. D. Sutton, M. A. Lomax, J. C. Macrae, and G. E. Lobley. 1996. Leucine and protein metabolism in the lactating dairy cow mammary gland: Responses to supplemental dietary crude protein intake. J. Dairy Res. 63:209-222.

Calder, A. G., K. E. Garden, S. E. Anderson, and G. E. Lobley. 1999. Quantitation of blood and plasma amino acids using isotope dilution electron impact gas chromatography/mass spectrometry with $\mathrm{U}_{-}{ }^{13} \mathrm{C}$ amino acids as internal standards. Rapid Commun. Mass Spectrom. 13:2080-2083.

Calder, A. G., and A. Smith. 1988. Stable isotope ratio analysis of leucine and ketoisocaproic acid in blood plasma by gas chromatography/mass spectrometry. Use of tertiary butyldimethylsilyl derivatives. Rapid Commun. Mass Spectrom. 2:14-16.

CCAC (Canadian Council on Animal Care). 1993. Guide to Care and Use of Experimental Animals. Vol. 1, E. D. Offert, B. M. Cross, and A. A. McWilliam, ed. CCAC, Ottawa, Ontario, Canada.

Chamberlain, D. G. 1987. The silage fermentation in relation to the utilization of nutrients in the rumen. Process Biochem. 22:60-63.

Chen, X. B., and M. J. Gomes. 1992. Estimation of microbial protein supply to sheep and cattle based on urinary excretion of purine derivatives-An overview of the technical details. Int. Feed Res. Unit, Occ. Publ., Rowett Research Institute, Bucksburn, Aberdeen, UK.

Cochran, W. G., and G. M. Cox. 1957. Experimental Designs. 2nd ed. John Wiley \& Sons Inc., New York, NY.

Dubois, M., K. A. Gilles, J. K. Hamilton, P. A. Rebers, and F. Smith. 1956. Colorimetric method for determination of sugars and related substances. Anal. Chem. 28:350-356.

Huhtanen, P. 1998. Supply of nutrients and productive responses in dairy cows given diets based on restrictively fermented silage. Agric. Food Sci. Finl. 7:219-250.

Huhtanen, P., H. O. Miettinen, and V. F. J. Toivonen. 1997. Effects of silage fermentation and post-ruminal casein supplementation in lactating dairy cows: 1 . Diet digestion and milk production. J. Sci. Food Agric. 74:450-458.

Jaakkola, S., and P. Huhtanen. 1992. Rumen fermentation and microbial protein synthesis in cattle given intraruminal infusions of lactic acid with a grass silage based diet. J. Agric. Sci. 119:411-418.
Jaakkola, S., P. Huhtanen, and V. Kaunisto. 1993. The effect of formic acid application rate at ensiling on the utilization of grass silage nitrogen in cattle. Pages 253-254 in Proc. VII World Conf. on Anim. Prod., Edmonton, Canada. University of Alberta, Edmonton, Canada.

Keady, T. W. J., J. J. Murphy, and D. Harrington. 1995. The effects of ensiling on dry-matter intake and milk production of lactating dairy cattle given forage as sole feed. Grass and Forage Sci. 51:131-141.

Kung, L., and R. E. Muck. 2006. Preservation of protein during harvest and storage. J. Dairy Sci. 89(Suppl. 1):449. (Abstr.)

Lapierre, H., J. P. Blouin, J. F. Bernier, C. K. Reynolds, P. Dubreuil, and G. E. Lobley. 2002. Effect of supply of metabolizable protein on whole body and splanchnic leucine metabolism in lactating dairy cows. J. Dairy Sci. 85:2631-2641.

Larsen, M., T. G. Madsen, M. R. Weisbjerg, T. Hvelplund, and J. Madsen. 2000. Endogenous amino acid flow in the duodenum of dairy cows. Acta Agric. Scand., Anim. Sci. 50:161-173.

Lobley, G. E., V. Milne, J. M. Lovie, P. J. Reeds, and K. Pennie. 1980. Whole body and tissue protein synthesis in cattle. Br. J. Nutr. 43:491-502.

Lobley, G. E., X. Shen, G. Le, D. M. Bremner, E. Milne, A. G. Calder, S. E. Anderson, and N. Dennison. 2003. Oxidation of essential amino acids by the ovine gastrointestinal tract. Br. J. Nutr. 89:617-630.

Martin, P. A., D. G. Chamberlain, S. Robertson, and D. Hirst. 1994. Rumen fermentation patterns in sheep receiving silages of different chemical composition supplemented with concentrates rich in starch or in digestible fibre. J. Agric. Sci. 122:145-150.

Martineau, R., H. Lapierre, D. R. Ouellet, D. Pellerin, and R. Berthiaume. 2005. Estimation of duodenal microbial N flow: Level of agreement between two methods of analysis. J. Dairy Sci. 88(Suppl. 1):316. (Abstr.)

Martineau, R., H. Lapierre, D. R. Ouellet, D. Pellerin, and R. Berthiaume. 2006. In situ degradation of timothy conserved as restrictively or extensively fermented silage or as hay. Can. J. Anim. Sci. 86:299-306.

McDonald, P., A. R. Henderson, and S. J. E. Heron. 1991. The biochemistry of silage. 2nd ed. Chalcombe Publications, Marlow, UK.

Miettinen, H. O., and P. J. Huhtanen. 1997. Effects of silage fermentation and post-ruminal casein supplementation in lactating dairy cows. 2. Energy metabolites and plasma amino acids. J. Sci. Food Agric. 74:459-468.

Novozamsky, I., R. van Eck, J. C. van Schouwenburg, and I. Walinga. 1974. Total nitrogen determination in plant material by means of the indophenol-blue method. Neth. J. Agric. Sci. $22: 3-5$.

NRC. 2001. Nutrient Requirements of Dairy Cattle. 7th rev. ed. Nat Acad. Press, Washington, DC.

Raggio, G., G. E. Lobley, S. Lemosquet, H. Rulquin, and H. Lapierre. 2006. Effect of casein and propionate supply on whole body protein metabolism in lactating dairy cows. Can. J. Anim. Sci. 86:81-89.

Read, W. W., M. A. Read, M. J. Rennie, R. C. Griggs, and D. Halliday. 1984. Preparation of $\mathrm{CO}_{2}$ from blood and protein-bound amino acid carboxyl groups for quantification and ${ }^{13} \mathrm{C}$-isotope measurements. Biomed. Mass Spectrom. 11:348-352.

Robertson, J. B., and P. J. Van Soest. 1981. The detergent system of analysis and its application to human foods. Pages 123-158 in The Analysis of Dietary Fiber in Foods. W. P. T. James and O. Theander, ed. Marcel Dekker, New York, NY.

Roe, M. B., L. E. Chase, and C. J. Sniffen. 1990. Techniques for measuring protein fractions in feedstuffs. Proc. Cornell Nutr. Conf. Feed Manuf., Syracuse, NY, Cornell Univ., Ithaca, NY.

SAS Institute. 2000. SAS/STAT User's Guide. Release 8.02. SAS Inst. Inc., Cary, NC.

Shingfield, K. J., S. Jaakkola, and P. Huhtanen. 2002. Effect of forage conservation method, concentrate level and propylene glycol on diet digestibility, rumen fermentation, blood metabo- 
lite concentrations and nutrient utilisation of dairy cows. Anim. Feed Sci. Technol. 97:1-21.

Siddons, R. C., J. Paradine, D. E. Beever, and P. R. Cornell. 1985. Ytterbium acetate as a particulate-phase digesta-flow marker. Br. J. Nutr. 54:509-519.

Swaisgood, H. E. 1995. Protein and amino acid composition of bovine milk. Pages 464-468 in Handbook of Milk Composition. R. G. Jensen, ed. Academic Press, Toronto, Ontario, Canada.

Vagnoni, D. B., and G. A. Broderick. 1997. Effects of supplementation of energy or ruminally undegraded protein to lactating cows fed alfalfa hay or silage. J. Dairy Sci. 80:1703-1712.

Van Soest, P. J. 1994. Microbes in the gut. Pages 253-280 in Nutritional Ecology of the Ruminant. 2nd ed. Comstock Pub., Ithaca, NY.
Van Soest, P. J., J. B. Robertson, and B. A. Lewis. 1991. Symposium: Carbohydrate methodology, metabolism and nutritional implications in dairy cattle. Methods for dietary fiber, neutral detergent fiber, and nonstarch polysaccharides in relation to animal nutrition. J. Dairy Sci. 74:3583-3597.

van Vuuren, A. M., P. Huhtanen, and J. P. Dulphy. 1995. Improving feeding and health value of ensiled forages. Pages 279-307 in Recent Developments in the Nutrition of Herbivores. M. Journet, E. Grenet, M.-H. Farce, M. Theriez, and C. Demarquilly, ed. INRA Editions, Paris, France.

Verbič, J., E. R. Ørskov, J. Žgajnar, X. B. Chen, and V. ŽnidaršičPongrac. 1999. The effect of method of forage preservation on the protein degradability and microbial protein synthesis in the rumen. Anim. Feed Sci. Technol. 82:195-212. 